\title{
Salmonella population in waste water treatment installation (IPAK) at Pulo Gebang DKI Jakarta
}

Sri Budiarti, Iman Rusmana

\begin{abstract}
Abstrak
Demam tifoid dan gastroenteritis yang disebabkan oleh genus Salmonella merupakan masalah kesehatan sedunia. Serogrup bakteri tersebut dapat digunakan sebagai indikator keamanan makanan dan air dari suatu negara. Di Indonesia khususnya DKI Jakarta, tempat pengelolaan limbah (IPAK) berfungsi sebagai kontrol lingkungan. Salmonella telah diisolasi dari IPAK dengan menggunakan medium agar Salmonella Shigella. Populasi Salmonella menurun sampai 52,9\% dari limbah air sampai limbah padat. Pemeriksaan resistensi antibiotik dilakukan pada populasi tersebut dengan menggunakan metode Kirby-Bauer. Hasil yang didapat memperlihatkan bahwa 93\% dari galur yang diisolasi ternyata sensitif kloramfenikol dan 27\% sensitif tetrasiklin. Disarankan agar kontrol Salmonella pada lingkungan harus ditangani secara serius. Meskipun demikian kloramfenikol masih mempunyai kemungkinan sebagai obat pilihan yang baik.
\end{abstract}

\begin{abstract}
Human typhoid fever and gastro-enteritis caused by the genus Salmonella are world-wide health problems. The serogroups of this bateria can be used as an indicator on the food and water safety of a country. In Indonesia especially in DKI Jakarta, there is a waste treatment area (IPAK) serving as environmental control. Salmonella have been isolated from IPAK using Salmonella Shigella Agar Medium. Salmonella population have been tested using Kirby-Bauer method. The result show that $93 \%$ of the isolated strains are sensitive to chloramphenicol and $27 \%$ are sensitive to tetracycline. It is suggested that Salmonella control in those environments should be taken more seriosly. However chloramphenicol have a possibility as a good choice of drug.
\end{abstract}

Department of Biology, Faculty of Science and Mathematics,

Bogor Agriculture University, Indonesia 